\title{
Pengembangan Aplikasi Regresi Parameter Cuaca Berbasis Visual Basic For Application
}

\author{
http://dx.doi.org/10.28932/jutisi.v6i3.3038
}

\author{
Bayu Bagus Riyandiarto ${ }^{\# 1}$, Nanda Noor Fadjrin ${ }^{\otimes * 2}$ \\ Matematika,Universitas Nahdlatul Ulama Al Ghazali \\ Jln. Kemerdekaan Barat No.17 Kesugihan Cilacap Jawa Tengah 53274 \\ ${ }^{2}$ bagusz17@gmail. com \\ Matematika,Universitas Nahdlatul Ulama Al Ghazali \\ Jln. Kemerdekaan Barat No.17 Kesugihan Cilacap Jawa Tengah 53274 \\ ${ }^{2}$ nandanoorfadjrin@gmail.com
}

\begin{abstract}
This research is the development of the Microsoft Excel VBA application to perform regression analysis between weather parameters in terms of data centering measures (PAMER11). The combination of parameters and data centering measures obtained 55 parameters that can be combined into $1,677,255,139,725$ annual regression analysis outputs. The case study used in this study only calculates air humidity with temperature and air pressure observation variables, then the analysis results are compared with the results of the Excel Toolpak analysis data with the Anova. The development of this application method is carried out in 4 stages, namely: define, design, develop, adn dissemination. The defined stage includes analysis of the needs of researchers in the BMKG field, analysis coverage of the needs of BMKG in the form of regression analysis. The design stage includes format selection, application program selection, and initial design (prototype 1). The development stage includes validation (prototype 2) obtained a programming aspect value of 4.1325 valid criteria, comparison of Anova results from the output of the PAMER11 application and analysis of the Excel toolpak, the $f$-value is $2 \times 10^{-6}$ with a p-value of $99 \%$ which results in the two calculations are significantly equal, for the display aspect get a value of 4,8175 valid criteria, limited and field product trials (prototype 3), where a limited trial was carried out on all faculty lecturers getting a score of 4.2440 very good criteria. Field trials conducted on the BMKG Cilacap got a score of 4.8333 very good criteria and data analysis at each stage of development has been improved towards the application program.
\end{abstract}

Keywords - Development; Microsoft Excel; Visual Basic for Application (VBA); Regression Analysis; Weather Parameters

\section{PENDAHULUAN}

\section{A. Latar Belakang}

Model prediksi terdorong oleh kebutuhan terhadap ketersediaan data dan informasi yang aktual baik yang berbasis statistik maupun yang berdasarkan pendekatan stokastik. Berbagai pendekatan model telah banyak digunakan untuk prediksi iklim baik dengan model statisitik maupun model deterministik. Salah satu model prediksi menggunakan model statistik adalah dengan regresi.

Regresi digunakan [1],[2],[3] dalam memprediksi cuaca dalam tiga penelitian. Parameter yang diambil Fadholi adalah suhu dan kelembapan untuk memprediksi curah ataupun total hujan. Kesimpulan penelitian menyarankan untuk menambahkan parameter-parameter. Namun, dalam 10 tahun terakhir belum terdapat penelitian yang mengajukan parameter lebih banyak dari penelitiannya.

Parameter cuaca yang dapat digunakan dalam penelitian ini antara lain suhu, temperatur bola kering, temperatur bola basah, kelembapan udara, tekanan udara laut, tekanan udara darat, arah angin, kecepatan angin, visibility, titik embun dan curah hujan. Parameter tersebut dikombinasikan dengan ukuran pemusatan data dalam penelitian antara lain rata-rata, jumlah data, modus, nilai maksimal dan nilai minimal. Kombinasi antara parameter dan ukuran pemusatan data didapat 55 parameter yang dapat dikombinasikan menjadi 1.677.255.139.725 output analisis regresi tahunan. Karyawan BMKG terbiasa menggunakan data Synop berbasis Excel. Microsoft Excel dikembangkan karena menurut [4] bermanfaat dalam mendukung, memahami dan mengutarakan spesifikasi perangkat lunak. Aplikasi Microsoft Excel untuk memperkirakan cuaca dengan regresi parameter cuaca.

Cakupan analisis regresi yang dapat digunakan dalam aplikasi ini meliputi persamaan regresi, analisis jumlah kuadrat dan derajat bebas sumber varians, koefisien determinasi, kriteria model terbaik pengujian parameter model regresi linier serentak, pengujian parameter model regresi linier parsial, uji autokorelasi uji heteroskedasitisitas grafik observasi dan prediksi dan diagram jaring. Namun, studi kasus yang digunakan dalam penelitian ini hanya menghitung kelembapan udara dengan variabel observasi suhu dan tekanan udara untuk selanjutnya hasil analisis dibandingkan dengan hasil Excel Toolpak dengan uji Anova. 
Pengembangan Microsoft Excel juga dikombinasikan dengan VBA karena menurut [5] pengembangan software aplikasi olah data statistika berbasis VBA mudah dipakai dan dipahami. Selaras dengan hal tersebut pengembangan yang dilakukan [6] bahwa multimedia menggunakan VBA memiliki tampilan menjadi lebih dan praktis.

\section{B. Batasan Masalah}

Keterbatasan dalam penelitian ini bahwa aplikasi belum dapat menampilkan hasil analisis untuk tiap bulan dan hanya mencakup wilayah Cilacap, namun aplikasi juga bisa digunakan di wilayah lain setelah pengembangan dinyatakan.

\section{Rumusan Masalah}

Berdasarkan latar belakang yang telah dipaparkan di atas, maka dapat dirumuskan permasalahan dalam penelitian ini adalah Bagaimana hasil pengembangan aplikasi Microsoft Excel berbasis VBA untuk analisis regresi antar parameter cuaca ditinjau dari ukuran pemusatan data di BMKG Cilacap dan bagaimana kesesuaian hasil analisis regresi PAMER11 dan Data Analysis Toolpak Microsoft Excel pada studi kasus penghitungan kelembapan ditinjau suhu dan tekanan udara?

\section{Tujuan Penelitian}

Bedasarkan rumusan masalah di atas, maka tujuan penelitian ini diharapkan produk yang dikembangkan atau dihasilkan adalah aplikasi untuk membantu analisis regresi antar parameter cuaca agar peneliti BMKG dapat melakukan penelitian dengan kombinasi parameter data Synop.

\section{TINJAUAN PUSTAKA}

Berikut penelitian relevan yang di tampilkan dalam state of art pada gambar 1. Dari penelitian [1] - [17] tahun 2011 yang diunggah tahun 2013 tentang regresi cuaca terakhir memberikan saran untuk menambahkan prediktor atau. Namun, meskipun tahun 2020 sudah terdapat 5 parameter hal tersebut masih belum naik signifikan. Menimbang bahwa di BMKG data synop masih berbasis Excel,. Hal tersebut sesuai dengan [4] bahwa Microsot Excel masih sering digunakan dan sangat mudah untuk dipahami. Pengembangan aplikasi Excel untuk analisis regresi dengan menggunakan seluruh parameter yang terdapat pada data Synop Agar tampilan aplikasi lebih menarik dan praktis, aplikasi Excel dikombinasikan dengan useform yang tersedia pada Macro VBA Excel agar lebih profesional

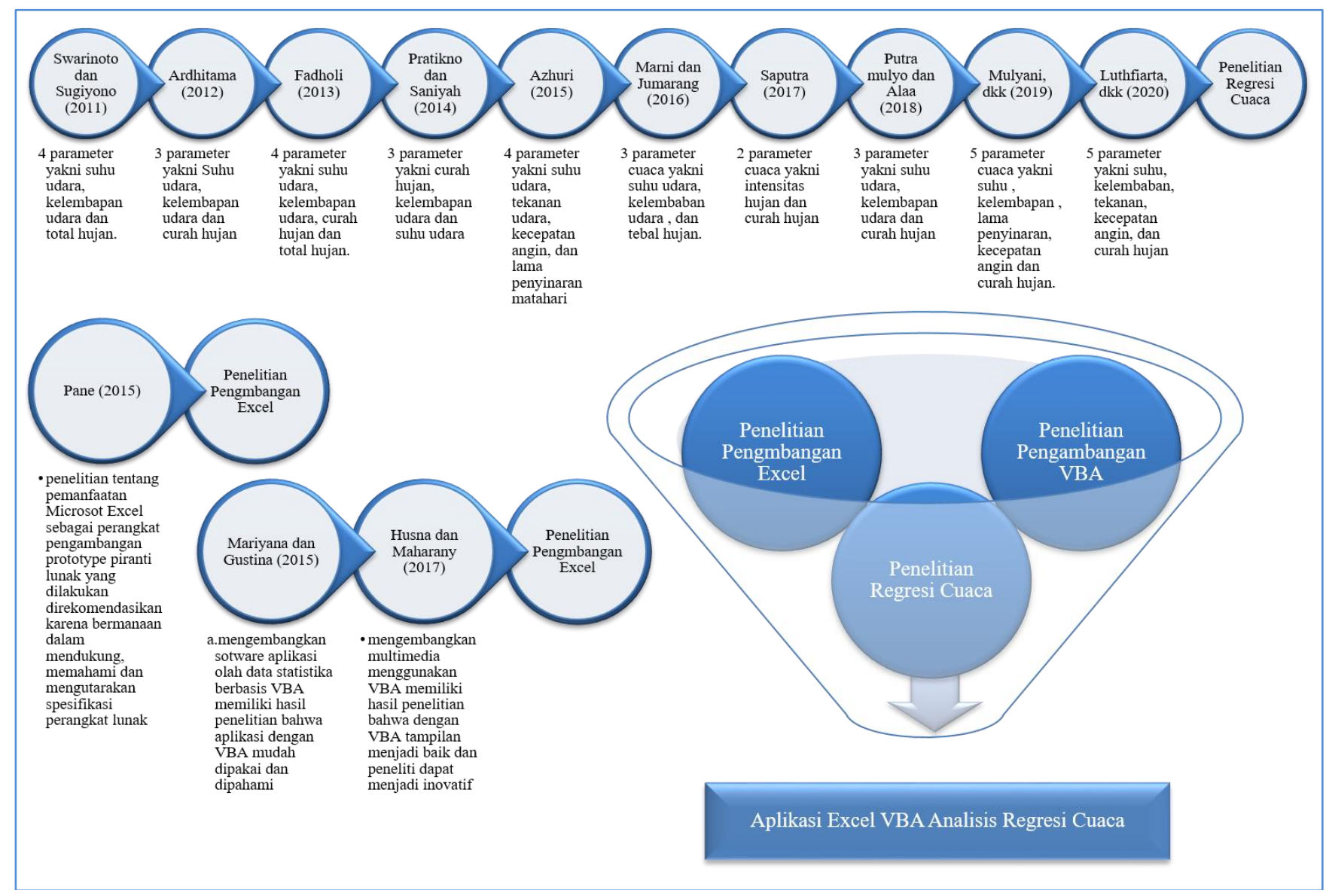

Gambar 1. State of Art Pengembangan Excel VBA Analisis Regresi Cuaca 


\section{LANDASAN TEORI}

\section{A. Parameter Cuaca}

Parameter cuaca menurut [19] merupakan variabelvariabel fisis yang mempengaruhi cuaca. Parameter tersebut sesuai data Synop BMKG Pusat yang telah seragam dengan seluruh BMKG se-Indonesia. Berikut penjelasan untuk tiaptiap parameter yang digunakan dalam penelitian ini menurut [20] dalam tabel I yang digunakan dalam penelitian.

TABEL I

Pengertian TiaP-TIAP PARAmeter CuACA

\begin{tabular}{|l|l|l|}
\hline \multicolumn{1}{|c|}{ No } & \multicolumn{1}{|c|}{ Parameter } & \multicolumn{1}{|c|}{ Pengertian } \\
\hline 1. & Suhu Udara & Besaran untuk menentukan panas udara \\
\hline 2. & Temperatur Bola Kering & Temperatur udara terjaga sinar matahari dan embun \\
\hline 3. & Temperatur Bola Basah & Temperatur udara yang didinginkan pada tekanan konstan \\
\hline 4. & Kelembapan Udara & Banyaknya kandungan uap di atmosfir \\
\hline 5. & Tekanan Udara Laut & Energi penggerak massa udara di laut \\
\hline 6. & Tekanan Udara Darat & Energi penggerak massa udara di darat \\
\hline 7. & Arah Angin & Arah menurut derajat mata angin \\
\hline 8. & Kecepatan Angin & Kecepatan aliran udara dari tekanan tinggi ke rendah \\
\hline 9. & Visibility & Tingkat kejernihan daripada atmosfer dalam jarak pandang \\
\hline 10. & Titik Embun & Suhu pada tekanan udara mengembun \\
\hline 11. & Curah Hujan & Jumlah air yang jatuh pada periode tertentu \\
\hline
\end{tabular}

\section{B. Analisis Regresi}

Berikut menurut Bonamente dalam [21]

1. Regresi Linier

$$
y=\beta_{0}+\sum_{i=1}^{n} \beta_{i}+\varepsilon_{i}
$$

dengan :

$y \quad: \quad$ nilai prediksi variabel

$\beta_{0}:$ nilai intersep model regresi

$\beta_{i}:$ koefisien regresi variabel prediktor ke-i

$x$ : Variabel observasi pengamatan ke-i

$\varepsilon_{i} \quad$ : error pada pengamatan ke-i asumsi

Pengujian Signifikasi Persamaan Regresi

$\begin{array}{lll}H_{0} & : & \beta_{1}=0 \\ H_{1} & : & \beta_{1} \neq 0\end{array}$

Berikut resume perhitungan ANOVA pada Tabel II

TABEL II

RESUME HASIL ANOVA

\begin{tabular}{|c|c|c|c|c|}
\hline$A$ & $S$ & $d f$ & $M$ & $F_{\_}$Hit \\
\hline$S R$ & $\sum_{i=1}^{n}\left(\hat{y}_{i}-\bar{y}\right)^{2}$ & $p$ & $\frac{S S R}{p}$ & $\frac{M S R}{M S E}$ \\
\hline$S E$ & $\sum_{i=1}^{n}\left(y_{i}-\bar{y}_{i}\right)^{2}$ & $q$ & $\frac{S S E}{q}$ & \\
\hline$S T$ & $\sum_{i=1}^{n}\left(y_{i}-\bar{y}\right)^{2}$ & $n-1$ & & \\
\hline
\end{tabular}

Statistik uji :

$$
F=\frac{M S R}{M S E}
$$

Daerah penolakan :

$\mathrm{H}_{0}$ ditolak,$F_{-}$Hitung $>F_{(\alpha ; p ; n-p-1)}$

Pengujian Signifikansi Parameter Regresi

$H_{0}: \beta_{1}=0$

$H_{1}: \beta_{1} \neq 0$

Statistik uji :

$t=\frac{\hat{\beta}_{1}}{\operatorname{SSE}\left(\hat{\beta}_{1}\right)}$

(3)

Daerah penolakan

$\mathrm{H}_{0}$ ditolak jika $|t|>t_{\left(\frac{\alpha}{2} ; q\right)}$

Pengujian Autokorelasi

$H_{0}: \rho=0$

$H_{1}: \rho \neq 0$

Stastistik uji :

$D W=\frac{\sum p^{2}}{\sum e_{t}^{2}}$

(4)

Berikut Kriteria Durin Watson pada Tabel III

TABEL III

KRITERIA DURBIN WATSON

\begin{tabular}{|c|l|}
\hline Kriteria Batas Kritis & \multicolumn{1}{c|}{ Kesimpulan } \\
\hline $0<D<D L$ & Autokorelasi Positif \\
\hline$D L \leq D \leq D U$ & Autokorelasi tidak jelas \\
\hline
\end{tabular}




\begin{tabular}{|c|l|}
\hline $4-D L<D<4$ & Autokorelasi Negatif \\
\hline $4-D U \leq D \leq 4-D L$ & Autokorelasi tidak jelas \\
\hline$D U<D<4-D U$ & Tidak ada Autokorelasi \\
\hline
\end{tabular}

\section{Uji Heterosdastistitas}

Variansi antar error yang satu dengan error yang lain berbeda. Dalam penelitian ini menggunakan uji Glejser yang memiliki langkah sama dengan regresi linier merupakan selisih prediktor dan observasi.

\section{Microsoft Excel VBA}

1. Microsoft Excel

Menurut [22] aplikasi Excel terkenal adalah formula dan fungsi digunakan untuk membantu beragam proses perhitungan secara cepat dan sederhana. Berikut langkah pembuatan apliksi Excel untuk analisis regresi parameter cuaca.

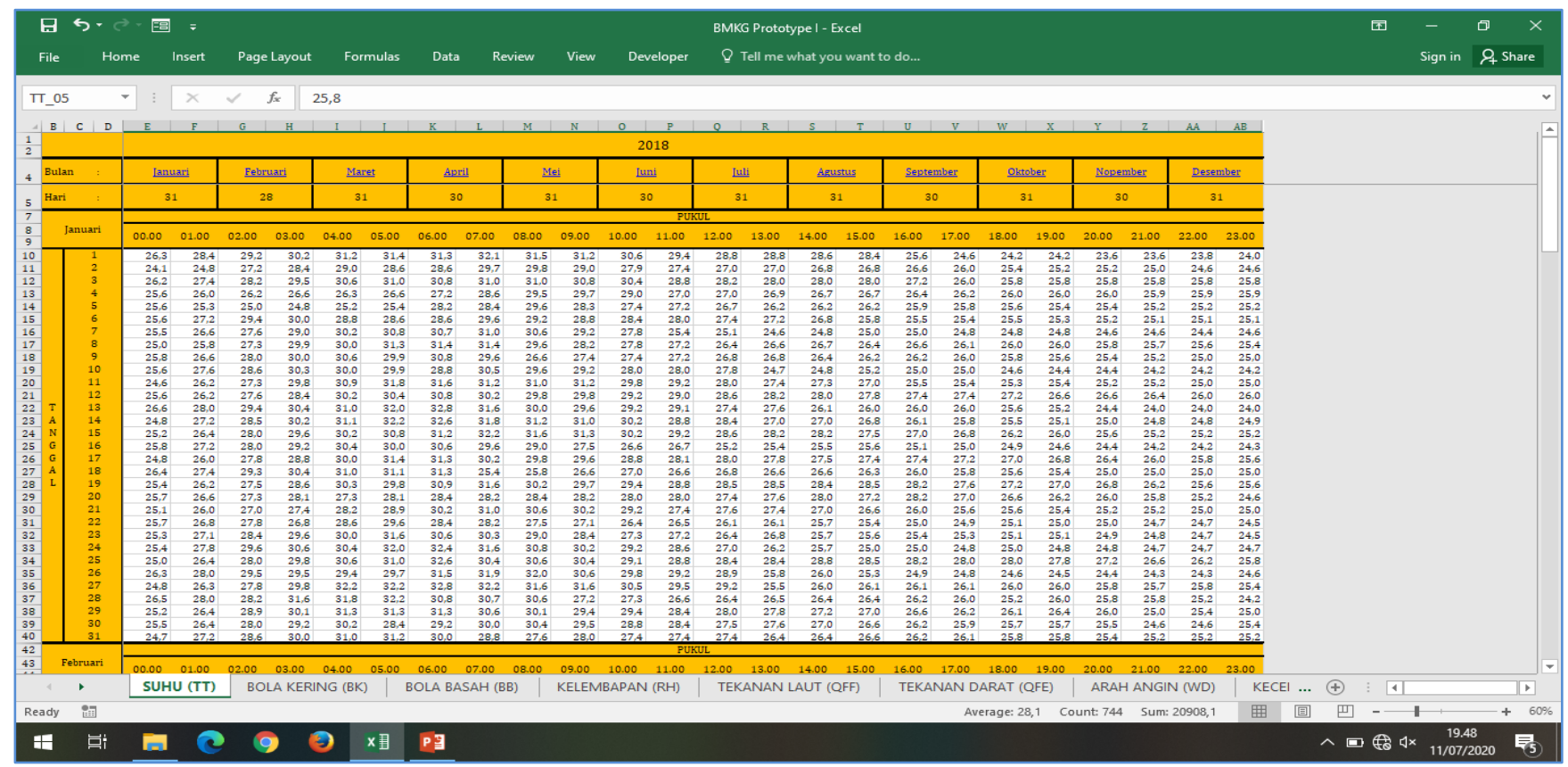

Gambar 2. Inputan Data Synop

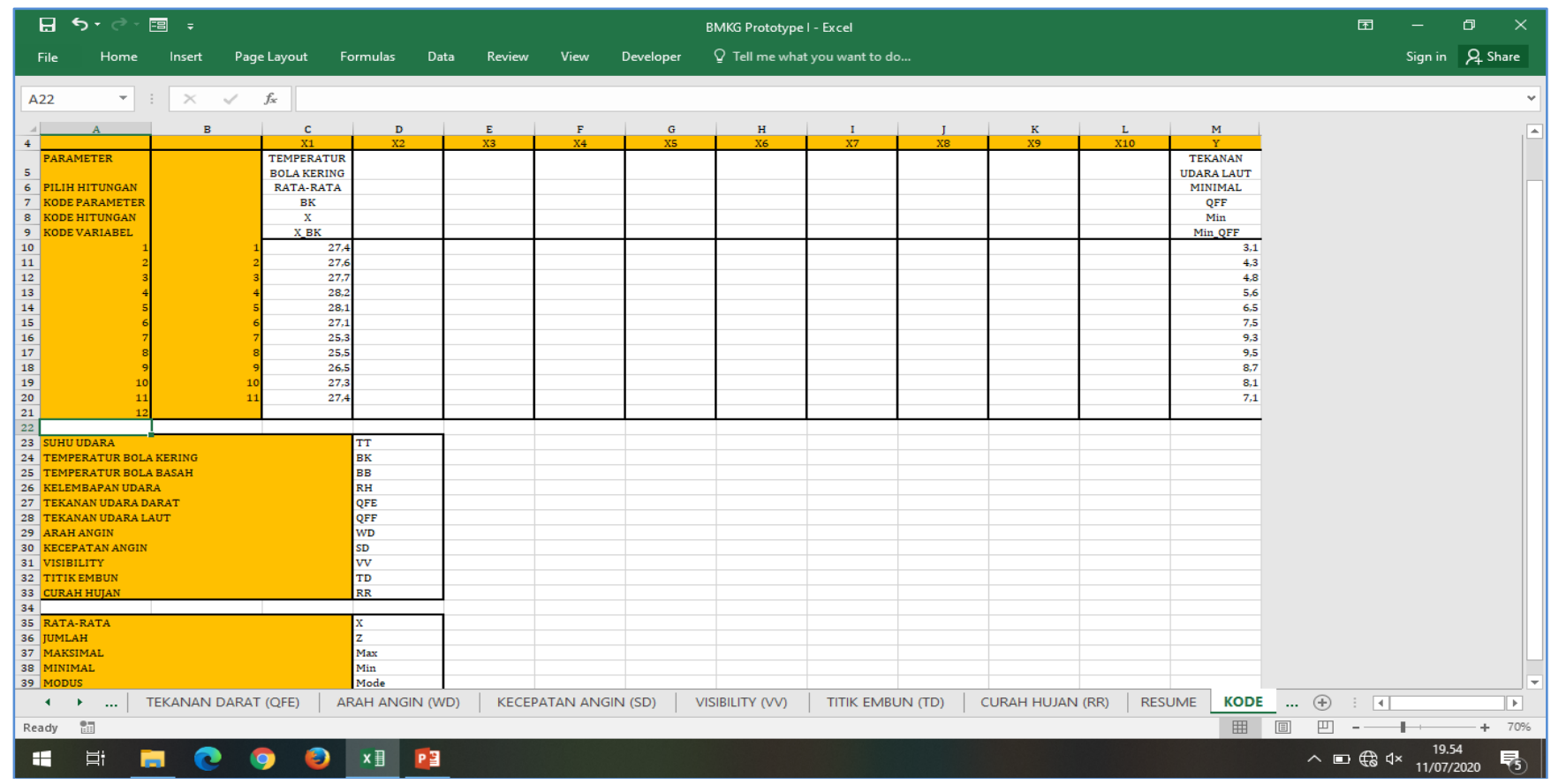

Gambar 3. Kode I Aplikasi Excel 


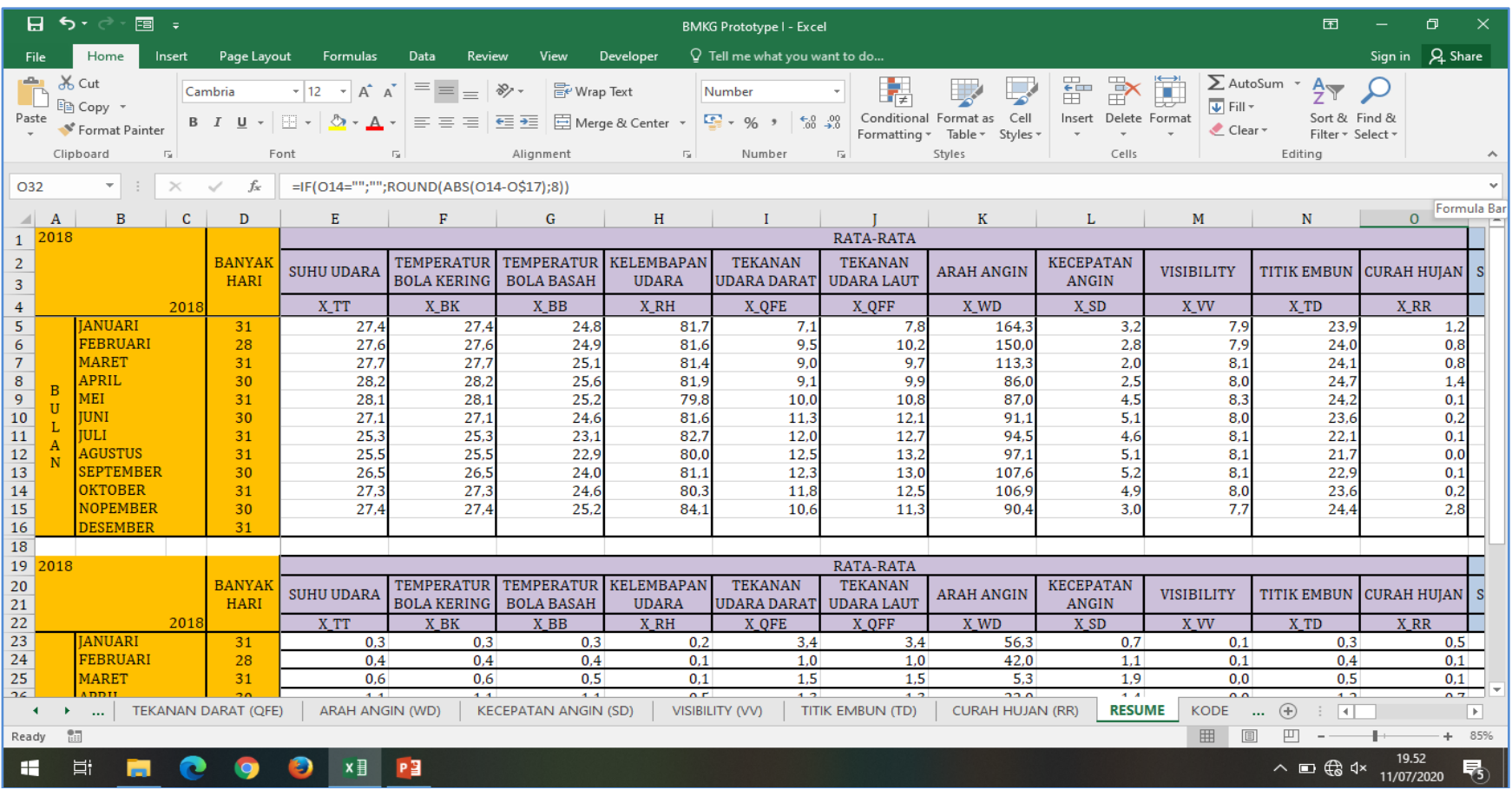

Gambar 4. Kode II Aplikasi Excel

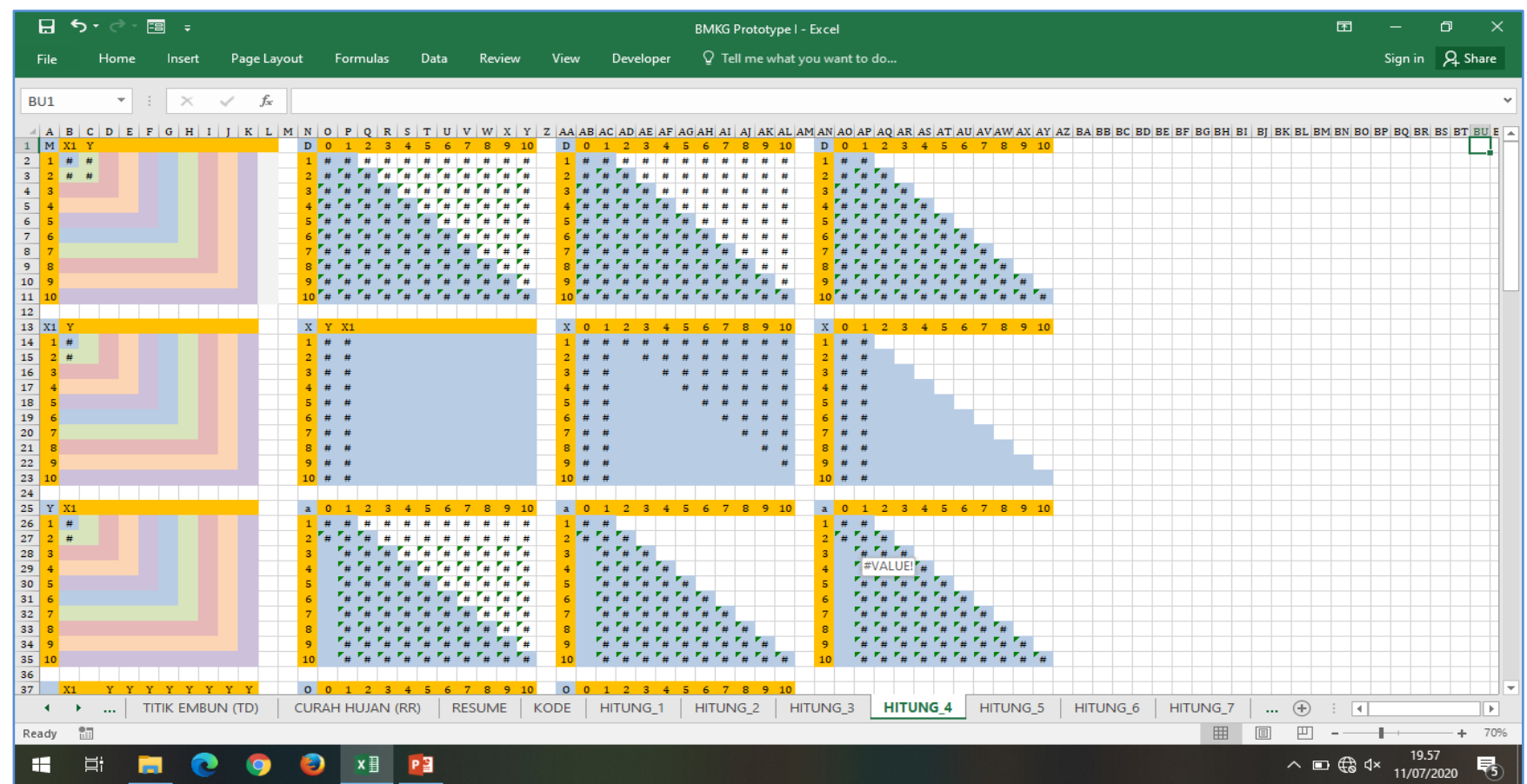

Gambar 5. Proses Hitung Analisis Aplikasi Excel 


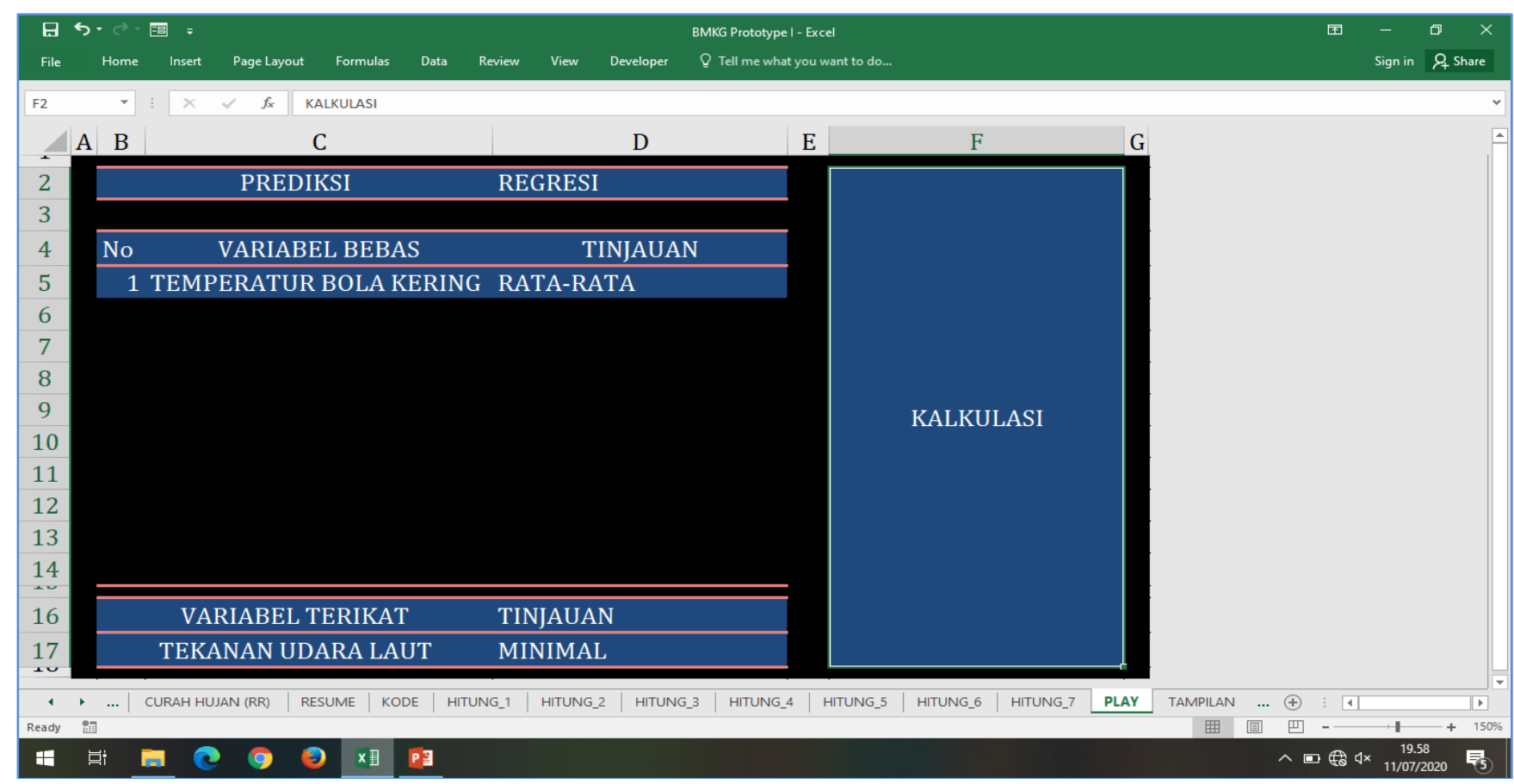

Gambar 6. Input Aplikasi Excel

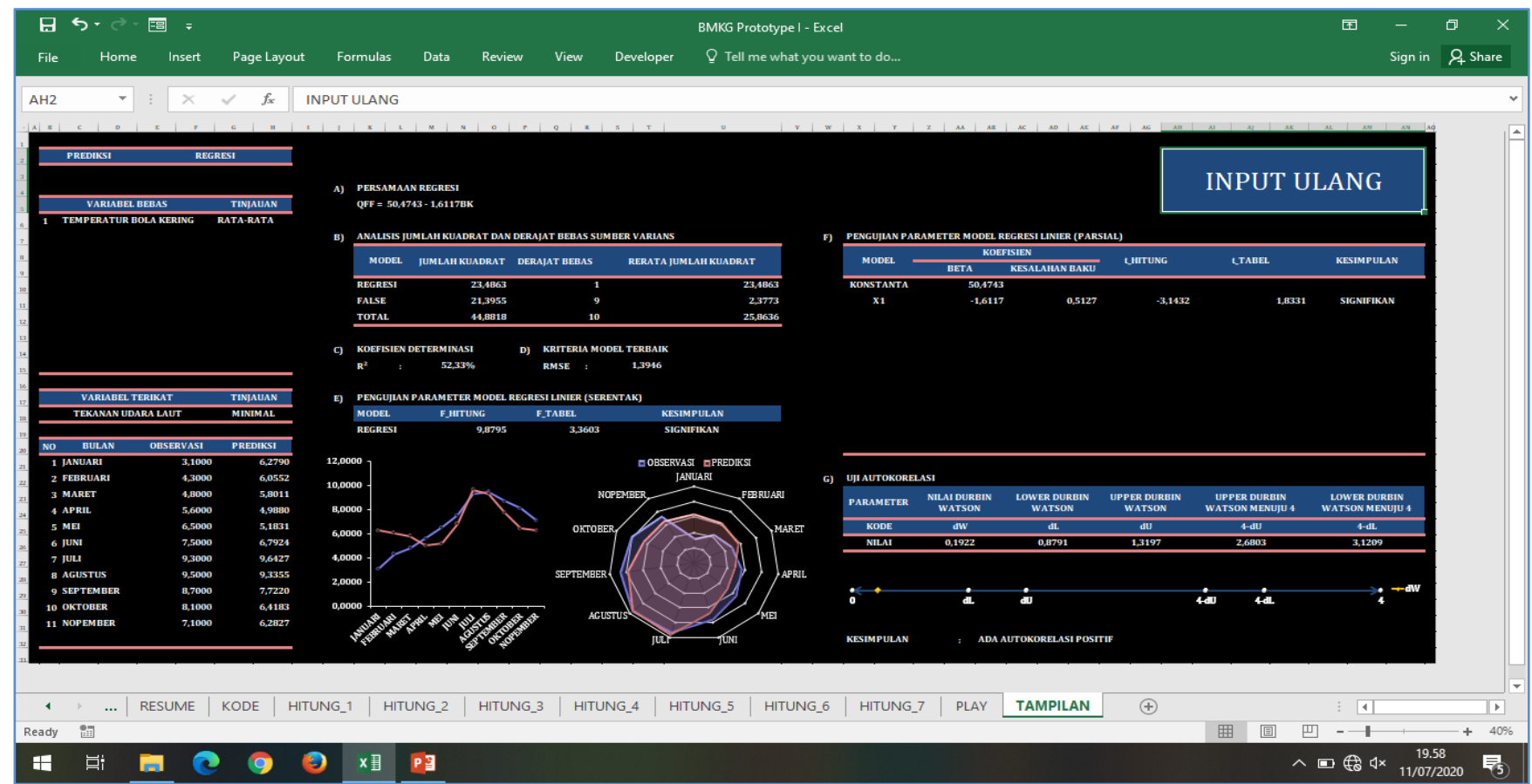

Gambar 7. Output Aplikasi Excel

Pada gambar 2. merupakan input data parameter diambil dari data synop dengan pemasukan setiap bulan pada tahun 2018. Pada gambar 3. merupakan pemberian kode parameter cuaca dan ukuran pemusatan data. Pada gambar 4. merupakan kombinasi kode parameter cuaca dan ukuran data. Pada gambar 5. merupakan proses statistika. Pada gambar 6. sel C6:14 merupakan input prediktor dan sel D6:D14 merupakan input pemusatan data. Lalu sel D17 merupakan input respon dengan D17 merupakan pemusatan data. Pada gambar 7. output sesuai input sheet sebelumnya. 
2. Visual Basic of Application (VBA)

Menurut [23] Macro merupakan rangkaian intruksi yang mengotomatisasi beberapa aspek dari Excel sehingga dapat bekerja dengan lebih efisien dan cepat. Dalam penelitian ini VBA yang digunakan ialah useform. Menurut [24] useform VBA merupakan tampilan visual pembuat database dengan input dan output. Rancangan useform yang disesuaikan coding yang digunakan mencakup listing pada combobox, checkbox, listbox, listview, picture dan label.

\section{METODE PENELITIAN}

\section{A. Model Pengembangan}

Berikut model 4-D (define, design, develop, and disemination) yang dikembangkan pada gambar 8. oleh Thiagarjan dalam [25] yang dimodifikasi.

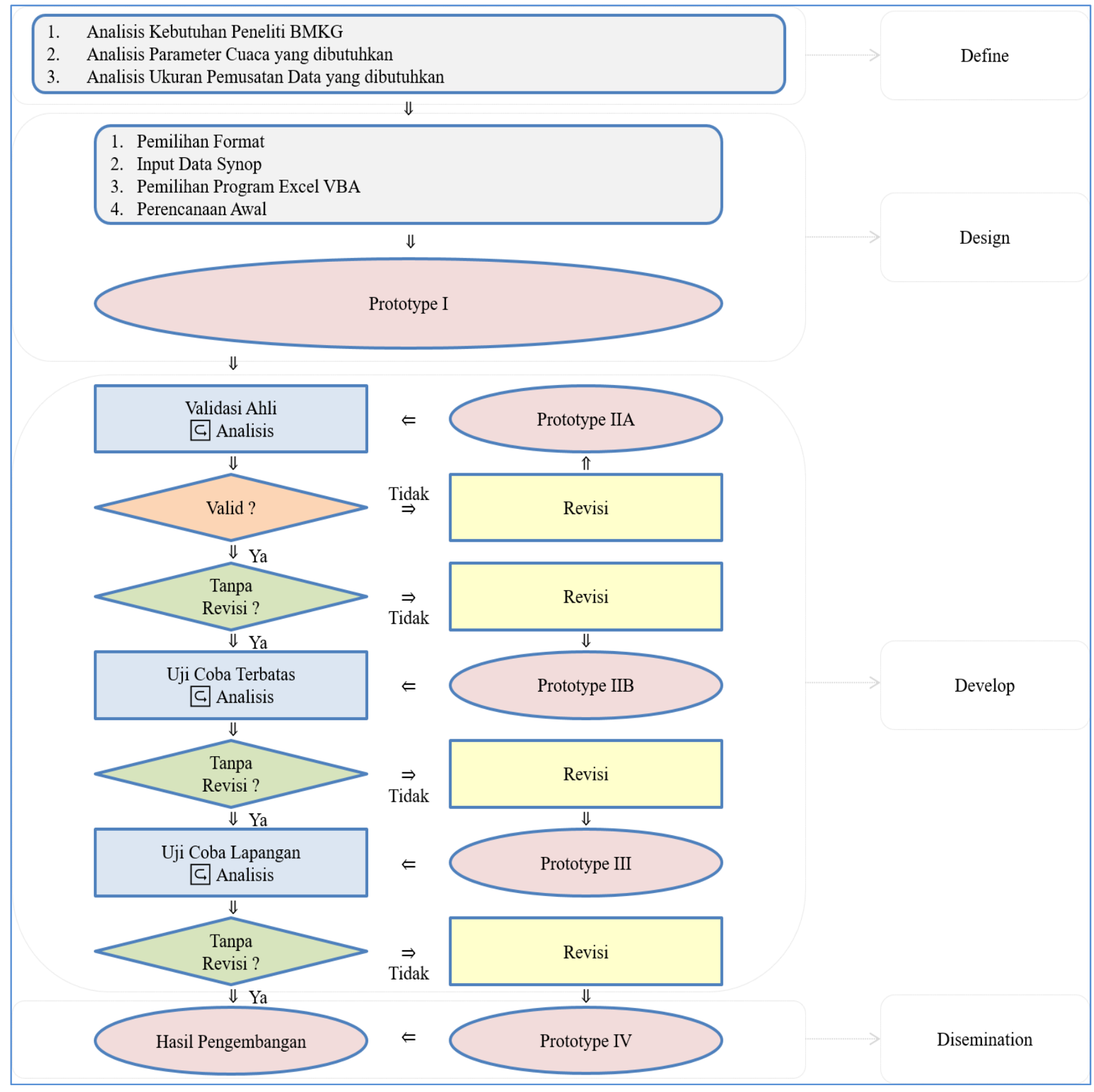

Gambar 8. Modifikasi Model 4-D Thiagarajan dalam Syaharuddin 


\section{B. Prosedur Pengembangan}

Prosedur pengembangan lebih lanjut merupakan penjelasan dari model pengembangan yang telah ditetapkan sebelumnya. Berikut langkah-langkah yang akan ditempuh dalam prosedur pengembangan ini. Tahap definisi, perencanaan, pengembangan validasi ahli. Validasi design produk awal (prototype I). Kegiatan ini bertujuan untuk mendapatkan penguatan ahli terhadap produk yang dikembangkan. Produk tersebut dikonsultasikan dan didiskusikan dengan para ahli untuk dievaluasi. Adapun kegiatan validasi ini dilakukan dalam bentuk isian validasi produk dan diskusi hingga produk valid dan layak untuk digunakan. Berikut daftar validator dalam penelitian ini pada tabel IV.

TABEL IV

DAFTAR VALIDATOR PRODUK

\begin{tabular}{|c|l|l|l|}
\hline No & Validator & Instansi & Bidang Ahli \\
\hline 1 & Najmah Istikaanah, M.Si & UNSOED & Statistika \\
\hline 2 & R. Wibowo, M.Pd & IAIIG Cilacap & Matematika \\
\hline 3 & MTA Zein, M.Kom & IAIIG Cilacap & Desain Grafis \\
\hline 4 & M Arifin, S.Kom & Multi Talenta & Desain Grafis \\
\hline 5 & Abd. Haq, M.Cs & UNUGHA & Pemrograman \\
\hline 6 & M. Arifin, S.Kom & Multi Talenta & Excel \\
\hline
\end{tabular}

Analisis Data Validasi, Data yang telah divalidasi oleh validator kemudian dianalisis, apabila masih terdapat kriteria validitas yang belum dipenuhi maka direvisi dan produk yang telah direvisi dan menjadi prototype II. Uji Coba Terbatas dan Analisis Data Uji kelompok terbatas dilakukan di seluruh dosen FMIKOM UNUGHA dengan pertimbangan utama pada Fakultas ini terdapat 4 dosen bidang Matematika sebagai pengamat bidang statistika, 2 dosen bidang Fisika pengamat bidang parameter cuaca, 3 dosen bidang Sistem Informasi dan 2 dosen bidang Teknologi Informatika pengamat bidang aplikasi. Dari analisis data uji coba ini akan direvisi dan menjadi prototype III. Uji Coba Lapangan dan Analisis Data Tahun pertama uji coba lapangan dilakukan di karyawan BMKG Cilacap menggunakan aplikasi sebagai alat bantu dalam penelitian dan pengembangan di BMKG Cilacap dan sebagai acuan untuk laporan tahunan. Dari analisis data uji coba ini akan direvisi dan menjadi prototype IV untuk dipaparkan.

\section{Uji Coba Produk}

1. Instrumen Pengumpulan Data Instrumen yang digunakan dalam penelitian ini antara lain: Lembar Validasi Ahli Angket Uji Coba Terbatas, dan Angket Uji Coba Lapangan.

2. Teknik Analisis Data

Berikut validitas dan respon subjek menurut Mulyadi dalam [25]
Rumus Validitas Penilaian Validator

$v=\frac{\sum_{i=1}^{n} v_{i}}{n}$

Respon Subjek Uji Coba Produk

$r=\frac{\sum_{i=1}^{n} r_{i}}{n}$

Berikut konversi nilai ke data kualitatif validitas dan tingkat respon pada tabel V dan VI.

TABEL V

TINGKAT VALIDITAS

\begin{tabular}{|c|c|}
\hline Interval & $\begin{array}{c}\text { Tingkat } \\
\text { Validitas }\end{array}$ \\
\hline$v=5$ & Sangat Valid \\
\hline $4 \leq v<5$ & Valid \\
\hline $3 \leq v<4$ & CukupValid \\
\hline $2 \leq v<3$ & Kurang Valid \\
\hline $1 \leq v<2$ & Tidak Valid \\
\hline
\end{tabular}

TABEL VI

TINGKAT RESPON

\begin{tabular}{|c|c|}
\hline Interval & $\begin{array}{c}\text { Tingkat } \\
\text { Respon }\end{array}$ \\
\hline $4<r \leq 5$ & Sangat Baik \\
\hline $3<r \leq 4$ & Baik \\
\hline $2<r \leq 3$ & CukupBaik \\
\hline $1<r \leq 2$ & Kurang Baik \\
\hline$r=1$ & Tidak Baik \\
\hline
\end{tabular}

\section{PEMBAHASAN}

\section{A. Validasi Produk}

\section{Aspek Pemrograman}

Produk divalidasi aspek pemrograman oleh dua validator pada bidang Pemrograman dan Microsoft Excel. Siklus I merupakan validasi awal dimana terdapat masukan untuk diperbaiki dan divalidasi lagi pada Siklus II. Berikut perbandingan hasil validasi Siklus I dan Siklus II yang disajikan pada tabel VII.

Dari hasil validasi siklus I perbaikan produk pada aspek pemrograman mengacu pada hasil validasi siklus I yakni jendela Excel yang semula muncul pada gambar 9. indeks (P-01A) menjadi tidak muncul jendela Excel indeks (P-01B). Untuk menginput data Synop diperlukan link menuju lembar kerja Excel yang mula-mula pada indeks (P-02A) menjadi tesedia indeks (P-02B) juga link untuk kembali ke useform yang tersedia di indeks (P-03B). Sedangkan tutorial pemakaian produk https://youtu.be/KdYeh3gT_jA. Setelah melakukan perbaikan hasil validasi naik dari 3,6250 (cukup valid) menjadi 4,2500 (valid) dan telah layak untuk diuji coba pada aspek pemrograman 
TABEL VII

HASIL VALIDASI ASPEK PEMROgRAMAN

\begin{tabular}{|c|c|c|c|c|c|}
\hline \multirow{2}{*}{ No } & \multirow{2}{*}{ Indikator } & \multicolumn{2}{|c|}{ Siklus I } & \multicolumn{2}{|c|}{ Siklus II } \\
\hline & & Nilai & Kriteria & Nilai & Kriteria \\
\hline \multicolumn{2}{|c|}{ Efisiensi Media } & 3,2500 & Cukup Valid & 4,2500 & Valid \\
\hline 1 & Kemudahan Pemakaian Program & 3,0000 & Cukup Valid & 4,0000 & Valid \\
\hline 2 & Kemudahan Memilih Menu Program & 3,0000 & Cukup Valid & 4,0000 & Valid \\
\hline 3 & Kemudahan Berinteraksi Dengan Program & 3,0000 & Cukup Valid & 4,0000 & Valid \\
\hline 4 & Kemudahan Masuk Dan Keluar Dari Program & 4,0000 & Valid & 5,0000 & Sangat Valid \\
\hline \multicolumn{2}{|c|}{ Fungsi Tombol } & 3,5000 & Cukup Valid & 4,2500 & Valid \\
\hline 5 & Kemudahan Memahami Struktur Tombol & 3,5000 & Cukup Valid & 4,0000 & Valid \\
\hline 6 & Ketepatan Reaksi Tombol (Button) & 3,5000 & Cukup Valid & 4,5000 & Valid \\
\hline \multicolumn{2}{|c|}{ Kualitas Fisik } & 4,5000 & Valid & 4,5000 & Valid \\
\hline 7 & Kapasitas File Program Untuk Kemudahan Duplikasi/Penggandaan & 4,5000 & Valid & 4,5000 & Valid \\
\hline 8 & Kekuatan/Keawetan Program & 4,5000 & Valid & 4,5000 & Valid \\
\hline & Rata - rata & 3,6250 & Cukup Valid & 4,2500 & Valid \\
\hline
\end{tabular}

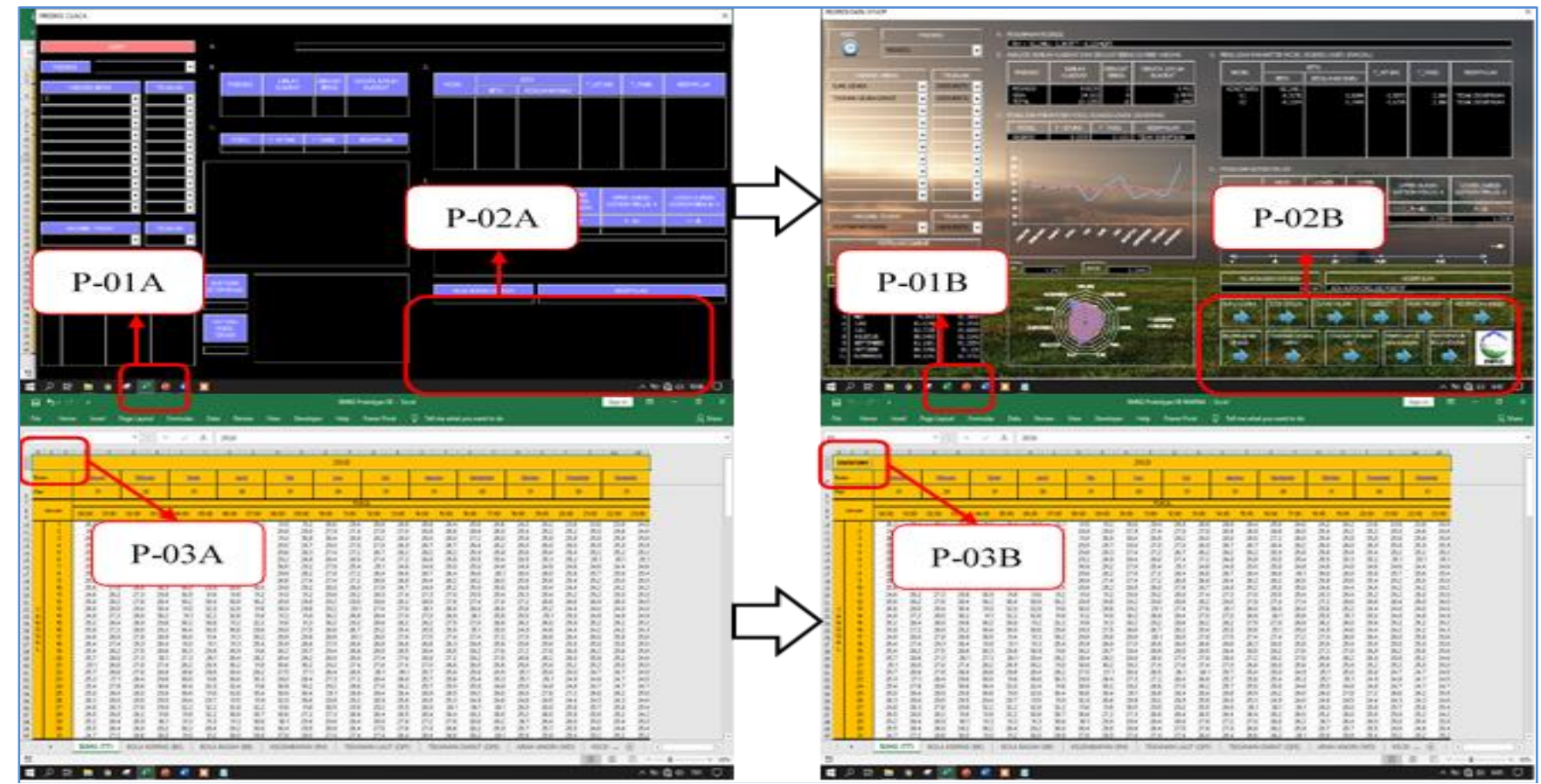

Gambar 9. Perbaikan Produk Aspek Pemrograman

2. Aspek Isi

Produk divalidasi dalam aspek isi oleh dua validator pada bidang Statistika dan Matematika. Siklus I merupakan validasi awal dimana terdapat masukan untuk diperbaiki dan divalidasi lagi pada Siklus II. Perbandingan hasil validasi antar pada tabel VIII. Dari hasil validasi siklus I perbaikan Produk pada aspek isi mengacu hasil validasi siklus I terdapat pada gambar 10 dan 11. yakni indeks (I-01A) dimana ketika suhu dengan tinjauan rata-rata diinput lalu suhu masih dapat dipilih dengan tinjauan yang sama diperbaiki pada indek (I-01B). Penggabungan regresi dan heteroskedatisitas telah diperbaiki pada indeks (I-02). Setelah melakukan perbaikan hasil validasi mengalami kenaikan yakni dari 3,5625 (cukup valid) menjadi 4,1250 (valid) dan layak untuk diuji pada aspek isi. 
TABEL VIII

HASIL VALIDASI ASPEK ISI

\begin{tabular}{|c|c|c|c|c|c|}
\hline \multirow{2}{*}{ No } & \multirow{2}{*}{ Indikator } & \multicolumn{2}{|c|}{ Siklus I } & \multicolumn{2}{|c|}{ Siklus II } \\
\hline & & Nilai & Kriteria & Nilai & Kriteria \\
\hline \multicolumn{2}{|c|}{ Kualitas Materi/Inputan } & 3,3333 & Cukup Valid & 4,3333 & Valid \\
\hline 1 & Tidak Ada Aspek (Inputan Dan Output) Yang Menyimpang & 4,0000 & Valid & 4,5000 & Valid \\
\hline 2 & Keluasan Cakupan Isi (Garis Besar Aplikasi) & 2,5000 & Kurang Valid & 4,0000 & Valid \\
\hline 3 & Kejelasan, Keluasan Dan Runtutan Inputan & 3,5000 & Cukup Valid & 4,5000 & Valid \\
\hline \multicolumn{2}{|c|}{ Kualitas Bahasa } & 3,5000 & Cukup Valid & 4,0000 & Valid \\
\hline 4 & Kejelasan Bahasa Yang Digunakan & 3,5000 & Cukup Valid & 4,0000 & Valid \\
\hline 5 & Kesesuaian Bahasa Dengan Sasaran Pengguna & 3,5000 & Cukup Valid & 4,0000 & Valid \\
\hline \multicolumn{2}{|c|}{ Kualitas Output/Pelaporan } & 3,8333 & Cukup Valid & 4,0000 & Valid \\
\hline 6 & Kesesuaian Jumlah Output Dengan Input & 3,5000 & Cukup Valid & 4,0000 & Valid \\
\hline 7 & Kesesuaian Output Dengan Aplikasi Profesional (Data Analysis Excel) & 4,0000 & Valid & 4,0000 & Valid \\
\hline 8 & Kemudahan Akses Output Setelah Penginputan & 4,0000 & Valid & 4,0000 & Valid \\
\hline & Rata - rata & 3,5625 & Cukup Valid & 4,1250 & Valid \\
\hline
\end{tabular}

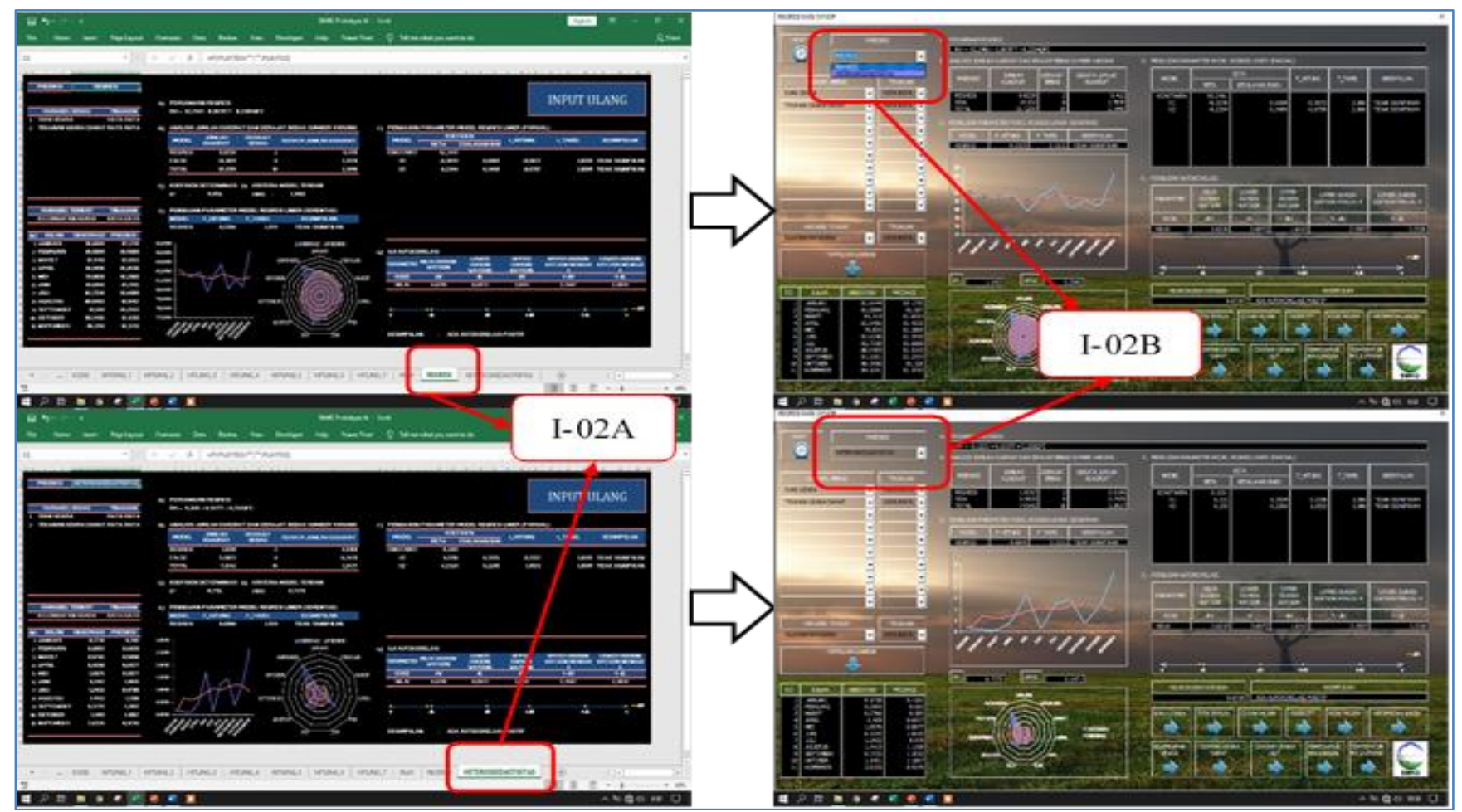

Gambar 10. Perbaikan Produk Aspek Isi Jilid I 


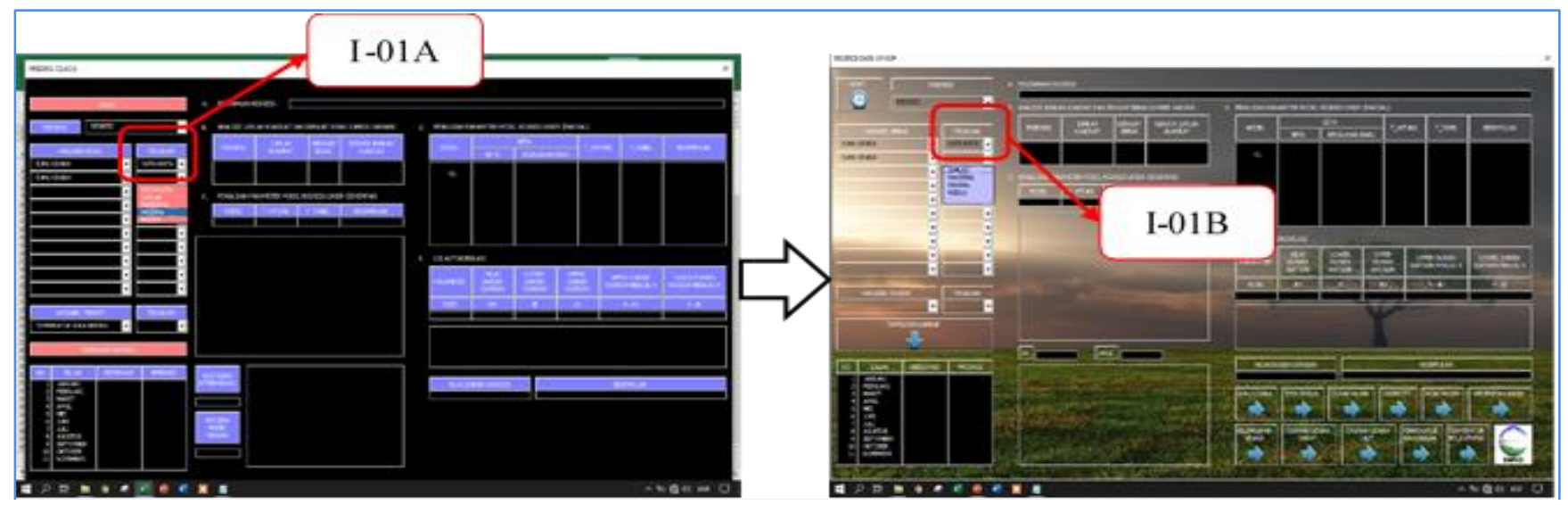

Gambar 11. Perbaikan Produk Aspek Isi Jilid II

3. Aspek Tampilan

Produk divalidasi dalam oleh dua validator Desain Grafis. Siklus I merupakan validasi awal dimana terdapat masukan untuk diperbaiki dan divalidasi pada Siklus II. Perbandingan hasil validasi antar siklus pada tabel IX. Dari hasil validasi siklus I perbaikan produk pada aspek tampilan mengacu hasil validasi siklus I terdapat pada gambar 12. yakni indeks (T-01B) telah ditambah logo BMKG, memperbaiki background indeks (T-02B), penambah ikon tombol (T-03B) dan ukuran lembar Excel (T04A) menjadi (T-04B). Setelah perbaikan naik dari 3,3125 (cukup valid) menjadi 4,1874 (valid) dan layak diuji coba pada aspek tampilan

TABEL IX

HASIL VALIDASI ASPEK TAMPILAN

\begin{tabular}{|c|c|c|c|c|c|}
\hline \multirow{2}{*}{ No } & \multirow{2}{*}{ Indikator } & \multicolumn{2}{|r|}{ Silkus I } & \multicolumn{2}{|c|}{ Siklus II } \\
\hline & & Nilai & Kriteria & Nilai & Kriteria \\
\hline \multicolumn{2}{|c|}{ Kualitas Tampilan } & 3,0833 & Cukup Valid & 4,0833 & Valid \\
\hline 1 & Tata Letak Inputan, Tombol, Dan Output & 3,0000 & Cukup Valid & 4,0000 & Valid \\
\hline 2 & Kesesuaian Pemilihan Background (Skins) & 2,0000 & Kurang Valid & 4,0000 & Valid \\
\hline 3 & Kesesuaian Pemilihan Ukuran Dan Jenis Huruf & 4,5000 & Valid & 4,5000 & Valid \\
\hline 4 & Kesesuaian Warna & 2,5000 & Kurang Valid & 4,0000 & Valid \\
\hline 5 & Kesesuaian Pemilihan Icon Dengan Tombol & 2,5000 & Kurang Valid & 4,0000 & Valid \\
\hline 6 & Kesesuaian Ukuran Aplikasi Dengan Layar Komputer & 4,0000 & Valid & 4,0000 & Valid \\
\hline \multicolumn{2}{|c|}{ Kualitas Tombol } & 4,0000 & Valid & 4,5000 & Valid \\
\hline 7 & Kemenarikan Tampilan Tombol (Button) & 3,0000 & Cukup Valid & 4,0000 & Valid \\
\hline 8 & Keteraturan Dan Konsistensi Tampilan Tombol & 5,0000 & Sangat Valid & 5,0000 & Sangat Valid \\
\hline & Rata - rata & 3,3125 & Cukup Valid & 4,1875 & Valid \\
\hline
\end{tabular}




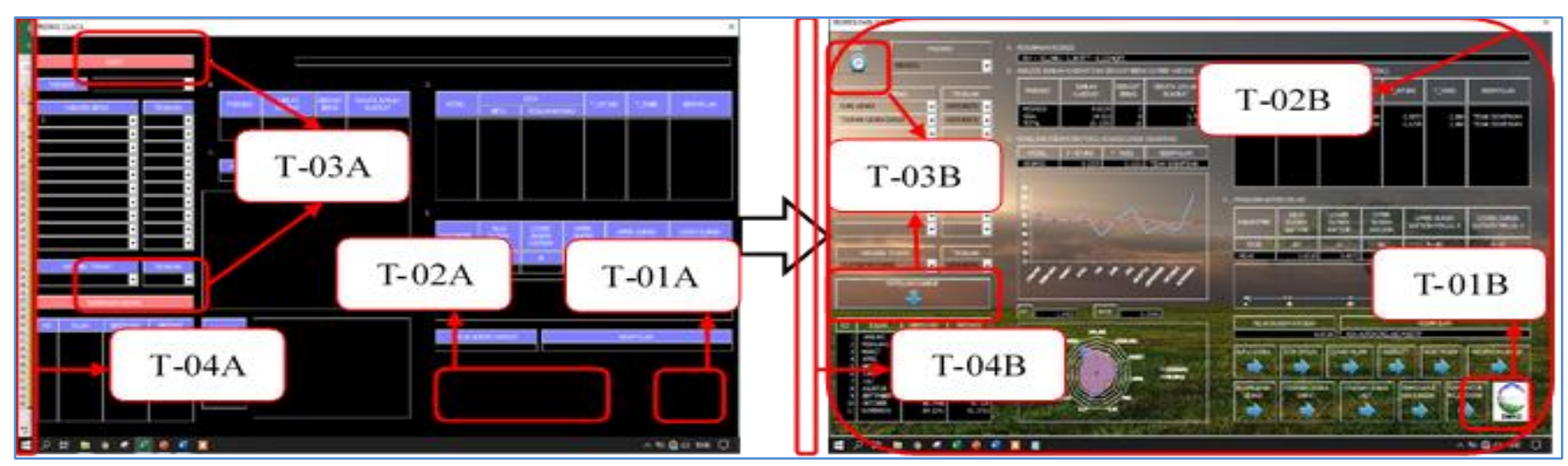

Gambar 12. Perbaikan Produk Aspek Tampilan

\section{B. Hasil Analisis Studi Kasus}

Perbandingan hasil output Produk pengembangan Excel VBA dan Data Analysis yang terdapat pada Microsoft Excel penghitungan kelembaban udara ditinjau dari suhu dan tekanan. Berikut hasil perhitungan aplikasi statistika regresi pada gambar 13. dan tabel X. Perhitungan dengan analisis data analysis toolpak didapat nilai F_Hitung $2 \times 10^{-6}$ dengan P-Value $99 \%$ perhitungan sama secara signifikan

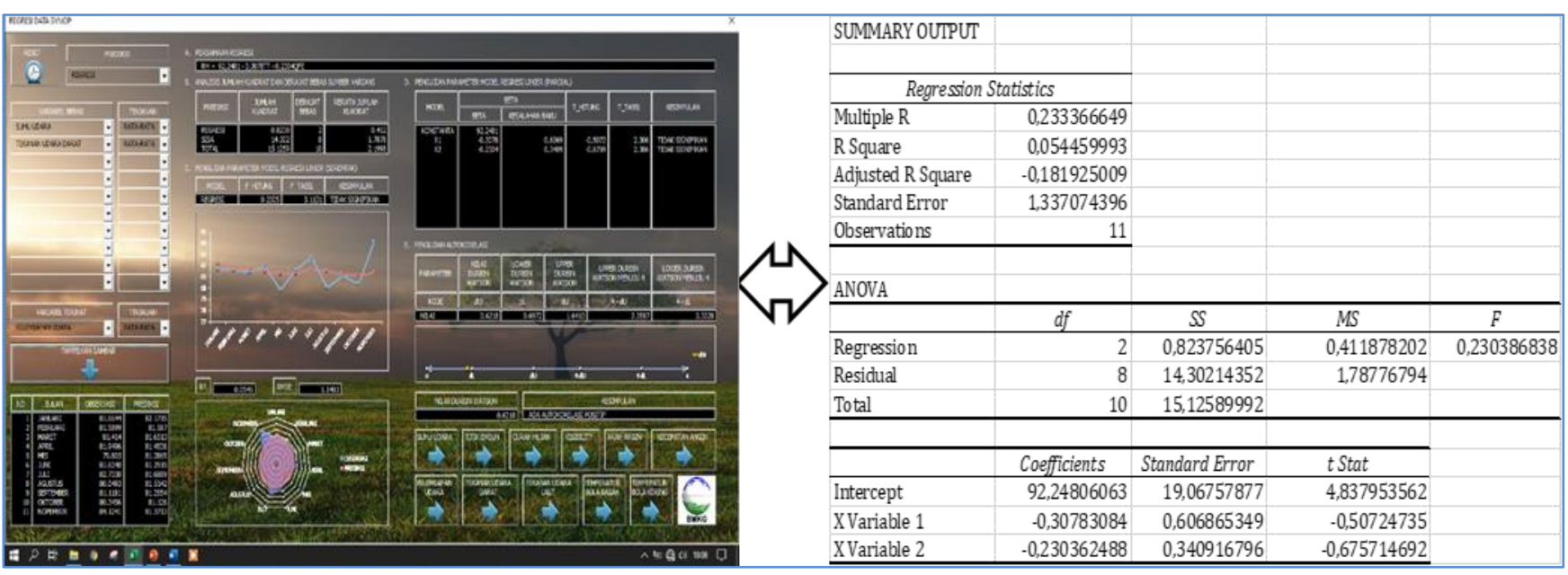

Gambar 13. Perbandingan perhitungan Produk dan Data Analysis Toolpak Microsoft Excel

TABEL $X$.

HASIL PERHITUNGAN REGRES

\begin{tabular}{|c|c|c|c|c|c|c|c|}
\hline No & Item & Analysis Toolpack & PAMER11 & No & Item & Analysis Toolpack & PAMER11 \\
\hline 1 & Intercept (Y) & 92,2481 & 92,2481 & 9 & Residual (SS) & 14,3021 & 14,3020 \\
\hline 2 & $\mathrm{X}$ Variable 1 (X1) & $-0,3078$ & $-0,3078$ & 10 & Total (SS) & 15,1259 & 15,1259 \\
\hline 3 & $\mathrm{X}$ Variable 2 (X2) & $-0,2304$ & $-0,2304$ & 11 & Regression (MS) & 0,4119 & 0,4120 \\
\hline 4 & R Square & 0,0545 & 0,0545 & 12 & Residual (MS) & 1,7878 & 1,7878 \\
\hline 5 & Regression (df) & 2,0000 & 2,0000 & 13 & $\mathrm{~F}$ & 0,2304 & 0,2305 \\
\hline 6 & Residual (df) & 8,0000 & 8,0000 & 14 & tStat $(\mathrm{X} 1)$ & $-0,5072$ & $-0,5072$ \\
\hline 7 & Total (df) & 10,0000 & 10,0000 & 15 & tStat $(\mathrm{X} 2)$ & $-0,6757$ & $-0,6759$ \\
\hline 8 & Regression (SS) & 0,8238 & 0,8239 & & & & \\
\hline
\end{tabular}


4. Uji Coba Produk

Setelah produk selesai divalidasi hingga siklus II lalu Produk diujicobakan secara bertahap. Tahap pertama diuji coba terbatas yakni pada pemakai dikalangan kampus UNUGHA dan tahap kedua pada karyawan BMKG. Berikut hasil uji coba produk secara terbatas maupun lapangan.Setelah produk selesai divalidasi hingga siklus II lalu Produk diujicoba secara bertahap. Tahap pertama di uji coba terbatas yakni pada pengguna di UNUGHA dan tahap kedua pada karyawan (khususnya kepala seksi) BMKG. Hasil uji coba terbatas delapan responden dari Fakultas Mikom didapatkan Nilai Rata-rata 4,2440 dengan predikat sangat baik dan uji coba lapangan yang diwakili oleh Kapoksi Stasiun BMKG Cilacap mendapat respon yang luar biasa dengan rata-rata 4,833 dengan predikat sangat baik sesuai tabel XI.

TABEL XI

HASIL RESPON UJI COBA PRODUK

\begin{tabular}{|c|c|c|c|c|c|}
\hline \multirow{2}{*}{ No } & \multirow{2}{*}{ Indikator } & \multicolumn{2}{|c|}{ Uji Coba Terbatas } & \multicolumn{2}{|c|}{ Uji Coba Lapangan } \\
\hline & & Nilai & Kriteria & Nilai & Kriteria \\
\hline \multicolumn{2}{|c|}{ Aspek Pemrograman } & 4,2656 & Sangat Baik & 4,7500 & Sangat Baik \\
\hline 1 & Kemudahan Pemakaian Program & 4,0000 & Baik & 5,0000 & Sangat Baik \\
\hline 2 & Kemudahan Memilih Menu Program & 3,8750 & Baik & 5,0000 & Sangat Baik \\
\hline 3 & Kemudahan Berinteraksi Dengan Program & 4,0000 & Baik & 5,0000 & Sangat Baik \\
\hline 4 & Kemudahan Masuk Dan Keluar Dari Program & 4,1250 & Sangat Baik & 5,0000 & Sangat Baik \\
\hline 5 & Kemudahan Memahami Struktur Tombol & 4,0000 & Baik & 4,0000 & Baik \\
\hline 6 & Ketepatan Reaksi Tombol (Button) & 4,1250 & Sangat Baik & 5,0000 & Sangat Baik \\
\hline 7 & Kapasitas File Program Untuk Kemudahan Duplikasi/Penggandaan & 5,0000 & Sangat Baik & 5,0000 & Sangat Baik \\
\hline 8 & Kekuatan/Keawetan Program & 5,0000 & Sangat Baik & 4,0000 & Baik \\
\hline \multicolumn{2}{|c|}{ Aspek Isi } & 4,2031 & Sangat Baik & 5,0000 & Sangat Baik \\
\hline 1 & Tidak Ada Aspek (Inputan Dan Output) Yang Menyimpang & 4,1250 & Sangat Baik & 5,0000 & Sangat Baik \\
\hline 2 & Keluasan Cakupan Isi (Garis Besar Aplikasi) & 3,8750 & Baik & 5,0000 & Sangat Baik \\
\hline 3 & Kejelasan, Keluasan Dan Runtutan Inputan & 3,7500 & Baik & 5,0000 & Sangat Baik \\
\hline 4 & Kejelasan Bahasa Yang Digunakan & 4,1250 & Sangat Baik & 5,0000 & Sangat Baik \\
\hline 5 & Kesesuaian Bahasa Dengan Sasaran Pengguna & 4,5000 & Sangat Baik & 5,0000 & Sangat Baik \\
\hline 6 & Kesesuaian Jumlah Output Dengan Input & 4,5000 & Sangat Baik & 5,0000 & Sangat Baik \\
\hline 7 & Kesesuaian Output Dengan Aplikasi Profesional (Data Analysis Excel) & 4,7500 & Sangat Baik & 5,0000 & Sangat Baik \\
\hline 8 & Kemudahan Akses Output Setelah Penginputan & 4,0000 & Baik & 5,0000 & Sangat Baik \\
\hline \multicolumn{2}{|c|}{ Aspek Tampilan } & 4,2656 & Sangat Baik & 4,7500 & Sangat Baik \\
\hline 1 & Tata Letak Inputan, Tombol, Dan Output & 4,0000 & Baik & 4,0000 & Baik \\
\hline 2 & Kesesuaian Pemilihan Background (Skins) & 4,2500 & Sangat Baik & 4,0000 & Baik \\
\hline 3 & Kesesuaian Pemilihan Ukuran Dan Jenis Huruf & 4,6250 & Sangat Baik & 5,0000 & Sangat Baik \\
\hline 4 & Kesesuaian Warna & 4,2500 & Sangat Baik & 5,0000 & Sangat Baik \\
\hline 5 & Kesesuaian Pemilihan Icon Dengan Tombol & 4,0000 & Baik & 5,0000 & Sangat Baik \\
\hline 6 & Kesesuaian Ukuran Aplikasi Dengan Layar Komputer & 4,0000 & Baik & 5,0000 & Sangat Baik \\
\hline 7 & Kemenarikan Tampilan Tombol (Button) & 4,0000 & Baik & 5,0000 & Sangat Baik \\
\hline \multirow[t]{2}{*}{8} & Keteraturan Dan Konsistensi Tampilan Tombol & 5,0000 & Sangat Baik & 5,0000 & Sangat Baik \\
\hline & Rata - rata & 4,2440 & Sangat Baik & 4,8333 & Sangat Baik \\
\hline
\end{tabular}




\section{KESIMPULAN DAN SARAN}

\section{A. Kesimpulan}

Berdasarkan tabel XII. terdapat peningkatan nilai semua indikator dari siklus I ke siklus II dengan hasil akhir kriteria valid untuk aspek pemrograman dengan rata-rata 4,1325. Berdasarkan tabel XIII. terdapat peningkatan nilai semua indikator dari siklus I ke siklus II dengan hasil akhir kriteria valid aspek isi dengan rata-rata 4,1250. Berdasarkan tabel XIV. terdapat peningkatan nilai semua indikator dari siklus I ke siklus II dengan hasil akhir kriteria valid untuk aspek tampilan dengan rata-rata 4,1875. Berdasarkan tabel $\mathrm{XV}$. terdapat peningkatan nilai semua indikator dari siklus I ke siklus II dengan hasil akhir uji coba terbatas dan lapangan kriteria sangat baik. Rata-rata nilai uji coba terbatas 4,2440 kriteria sangat baik dan uji lapangan 4,8333 kriteria sangat baik. Setelah Uji coba lapangan aplikasi telah diterima oleh BMKG Cilacap sebagai arsip aplikasi analisis cuaca.

TABEL XII

Resume Hasil Validasi Aspek Pemrograman

\begin{tabular}{|c|c|c|c|c|c|c|}
\hline & \multirow{2}{*}{ Indikator } & \multirow{2}{*}{ Bobot } & \multicolumn{2}{|c|}{ Siklus I } & \multicolumn{2}{|c|}{ Siklus II } \\
\hline & & & Nilai & Kriteria & Nilai & Kriteria \\
\hline A & Efisiensi Media & 0,5000 & 3,2500 & Cukup Valid & 4,2500 & Valid \\
\hline B & Fungsi Tombol & 0,2500 & 3,5000 & Cukup Valid & 4,2500 & Valid \\
\hline $\mathrm{C}$ & Kualitas Fisik & 0,2500 & 4,5000 & Valid & 4,5000 & Valid \\
\hline & & Rata - Rata & 3,6250 & Cukup Valid & 4,3125 & Valid \\
\hline
\end{tabular}

TABEL XIII

RESUME HASIL VALIDASI ASPEK ISI

\begin{tabular}{|l|l|c|c|c|c|c|}
\hline \multirow{2}{*}{\multicolumn{2}{|c|}{ Indikator }} & \multirow{2}{*}{ Bobot } & \multicolumn{2}{c|}{ Siklus I } & \multicolumn{2}{c|}{ Siklus II } \\
\cline { 4 - 8 } & & Nilai & Kriteria & \multicolumn{2}{c|}{ Nilai } & Kriteria \\
\hline A & Kualitas Materi/Inputan & 0,3750 & 3,3333 & Cukup Valid & 4,3333 & Valid \\
\hline B & Kualitas Bahasa & 0,2500 & 3,5000 & Cukup Valid & 4,0000 & Valid \\
\hline C & Kualitas Output/Pelaporan & 0,3750 & 3,8333 & Cukup Valid & 4,0000 & Valid \\
\hline & Rata - Rata & 3,5625 & Cukup Valid & 4,1250 & Valid \\
\hline
\end{tabular}

TABEL XIV

RESUME HASIL VALIDASI ASPEK TAMPILAN

\begin{tabular}{|l|l|c|c|c|c|c|}
\hline \multirow{2}{*}{\multicolumn{2}{|c|}{ Indikator }} & \multirow{2}{*}{ Bobot } & \multicolumn{2}{c|}{ Siklus I } & \multicolumn{2}{c|}{ Siklus II } \\
\cline { 4 - 8 } & & Nilai & Kriteria & \multicolumn{2}{c|}{ Nilai } & Kriteria \\
\hline A & Kualitas Tampilan & 0,7500 & 3,0833 & Cukup Valid & 4,0833 & Valid \\
\hline B & Kualitas Tombol & 0,2500 & 4,0000 & Valid & 4,5000 & Valid \\
\hline \multicolumn{2}{|c|}{} & Rata - Rata & 3,3125 & Cukup Valid & 4,1875 & Valid \\
\hline
\end{tabular}

TABEL XV

Resume Hasil Uji COBA PRODUK

\begin{tabular}{|l|l|c|c|c|c|c|}
\hline \multirow{2}{*}{\multicolumn{2}{|c|}{ Indikator }} & \multirow{2}{*}{ Bobot } & \multicolumn{2}{c|}{ Uji Coba Terbatas } & \multicolumn{2}{c|}{ Uji Coba Lapangan } \\
\cline { 4 - 8 } & & Nilai & Kriteria & \multicolumn{2}{c|}{ Nilai } & Kriteria \\
\hline A & Aspek Pemrograman & 0,3333 & 4,2656 & Sangat Baik & 4,7500 & Sangat Baik \\
\hline B & Aspek Isi & 0,3333 & 4,2031 & Sangat Baik & 5,0000 & Sangat Baik \\
\hline C & Aspek Tampilan & 0,3333 & 4,2656 & Sangat Baik & 4,7500 & Sangat Baik \\
\hline \multicolumn{2}{|c|}{ Rata - Rata } & 4,2440 & Sangat Baik & 4,8333 & Sangat Baik \\
\hline
\end{tabular}


Analisis data hasil perhitungan regresi dengan aplikasi Excel dan analysis Toolpack dibandingkan dengan uji Anava. Didapat F_Hitung $2 \times 10^{-6}$ dengan P-Value $99 \%$ secara signifikan atau dengan kata lain perhitungan PAMER11 sudah sesuai dengan aplikasi analysis Toolpack Excel.

\section{B. Saran}

Pihak BMKG seluruh Indonesia disarankan untuk menggunakan Aplikasi PAMER11 untuk analisis cuaca dan untuk Peneliti tentang BMKG disarankan menggunakan sebagai bahan kajian dalam penelitian agar memberikan prediksi cuaca yang lebih baik.

\section{DAFTAR PUSTAKA}

[1] Fadholi, A. "Persamaan Regresi Prediksi Hujan Bulanan di Pontianak dengan Prediktor Suhu dan Kelembapan Udara," Forum Ilmiah, vol. 10, no. 2, 2013

[2] Fadholi, A. "Persamaan Regresi Prediksi Curah Hujan Bulanan Menggunakan Data Suhu Dan Kelembapan Udara Di Ternate", Statistika, vol. 13, no. 1, pp. 7-16, 2013.

[3] Fadholi, A. "Pemanfaatan Suhu Udara Dan Kelembapan Udara Dalam Persamaan Regresi Untuk Simulasi Prediksi Total Hujan Bulanan Di Pangkalpinang," Jurnal CAUCHY, vol. 3, no. 2, 2013.

[4] Pane, I.Z. "Pemanfaatan Microsoft Excel Sebagai Perangkat Pengembangan Prototipe Piranti Lunak," Visual Ultima Inosys, vol. 06, no $1,2015$.

[5] Mariyana, R., dan Gustina, A. D. "Pengembangan Software Aplikasi Bantu Olah Data Statistika Berbasis VBA," Edutech Vol. 1, No. 1, 2015

[6] Husna, S. N., dan Maharany,. E. R.. "Pengembangan Multimedia Menggunakan Visual Basic for Application (VBA) untuk meningkatkan Profesionalisme Guru Matematika," Jurnal Pendidikan Matematika," vol. 3, no.2, pp. 30-40, 2017.

[7] Swarinoto, Y. S., dan Sugiyono. "Pemanfaatan Suhu Udara Dan Kelembapan Udara Dalam Persamaan Regresi Untuk Simulasi Prediksi Total Hujan,” Jurnal Meteorologi Dan Geofisika, vol. 12, no. 3, pp. 271- 281, 2011

[8] Ardhitama, A. "Simulasi Prakiraan Jumlah Curah Hujan Dengan Menggunakan Data Parameter Cuaca (Study Kasus Di Kota Pekanbaru Tahun 2012," Jurnal Sains \& Teknologi Modifikasi Cuaca, vol. 14, no. 2, pp. 111-117, 2013.

[9] Pratikno, B. dan Saniyah. "Regresi Linier Bivariat Simpel dan Aplikasinya Pada Data Cuaca di Cilacap," JMP, vol. 6, no.1, 2014.

[10] Azhuri. "Simulasi Prediksi Curah Hujan Bulanan di Kota Medan Menggunakan Regresi Linier Berganda,"Jurnal Einstein, vol. 2, no. 2, pp. 57-63, 2015
[11] Marni, dan Jumarang, M. I. "Analisis Hubungan Kelembaban Udara Dan Suhu Udara Terhadap Parameter Tebal Hujan di Kota Pontianak," Prisma Fisika, vol. 4, no. 3, pp. 80-83, 2016.

[12] Saputra, I. K. "Perhitungan Intensitas Hujan Berdasarkan Data Curah Hujan Stasiun Curah Hujan Di Kota Denpasar," Skripsi. Jurusan Teknik Sipil Fakultas Teknik Universitas Udayana, Denpasar, 2017.

[13] Putramulyo, S., dan Alaa, S. "Prediksi Curah Hujan Bulanan di Kota Samarinda Menggunakan Persamaan Regresi Dengan Prediktor Data Suhu Dan Kelembapan Udara Eigen," Mathematics Journal. vol. 1 No. 2, Desember 2018

[14] Mulyani, E. D. S., Septianingrum, I., Reka, N. N., Syifa, N. dan Kiki, M. "Prediksi Curah Hujan di Kabupaten Majalengka dengan Menggunakan Algoritma Regresi” Jurnal Sistem Informasi dan Teknologi Informasi, vol. 8, no. 1, 2019.

[15] Luthfiarta, A., Febriyanto, A., Lestiawan, H., dan Wicaksono, W. "Analisa Prakiraan Cuaca Dengan Parameter Suhu, Kelembaban, Tekanan Udara, Dan Kecepatan Angin Menggunakan Regresi Linear Berganda," Journal of Information System, vol. 5, no. 1, pp. 10-17, 2020

[16] Supriya, P., Krishnaveni, M., and Subbulakshmi, M.. "Regression Analysis of Annual Maximum Daily Rainfall and Stream Flow for Flood Forecasting in Vellar River Basin International Conference on Water Resources, Coastal and Ocean Engineering (Icwrcoe 2015)," Aquatic Procedia 4 Sciencedirect, pp. 957 - 963, 2015.

[17] MAI Navid, NH Niloy. "Multiple Linear Regressions or Predicting Rainfall for Bangladesh," Communications, vol. 6, no. 1, pp. 1-4, 2018.

[18] Asynuzar, N. "Pengembangan Aplikasi Pengolahan Data Cuaca Pada Stasiun Meteorologi Maritim Pontianak" Justin, vol.2, no.3, 2014.

[19] Tcahyono, B. "Meteorologi Indonesia Volume I: Karakteristik dan Sirkulasi Atmosfer. Jakarta: Pusat Penelitian dan Pengembangan Badan Meteorologi, Klimatologi dan Geofisika, 2009.

[20] Tcahyono, B., dan Harjino, S. B. Meteorologi Indonesia Volume II : Awan dan Hujan Morsun. Jakarta: Pusat Penelitian dan Pengembangan Badan Meteorologi, Klimatologi dan Geofisika, 2012.

[21] Fadjrin, N. N. dan Wibawa, A. "Pemodelan Deret Waktu Point Liga Italia Serie A Dengan Pendekatan Regresi Terkecil Berdasarkan RMSE (Root Mean Square Score) Terkecil dan Skor Maksimal Tiap Pekan," Jurnal Statistika, vol. 8, no. 2, pp. 78-87, 2020.

[22] Lesmana, A. Mengenal Formula Excel, Bandung: Medio Bandung. 2013

[23] Urtis, T. Excel VBA 24 Hour Trainer, Indiana: Wiley Publishing. 2011

[24] More, M. Mastering Excel Useforms, Copyright: Mark More. 2015.

[25] Syaharuddin, Febriana, E., dan Mandalina, V. "Kombinasi Delphi XE8 dan Ms Acces Dalam Desain DASS," Jurnal Riset Teknologi dan Inovasi Pendidikan, vol. 1, no.2, pp. 1-8, 2018 